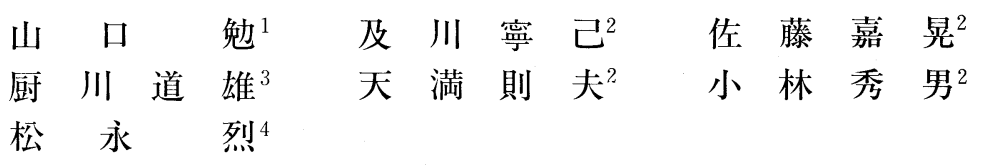

[UDC $622.83 ; 624.121 .38$ ]

\section{Experimental Study on Determination of In-situ Stress State by DSCA}

by Tsutomu YAMAGUCHI ${ }^{1}$, Yasuki OIKAWA ${ }^{1}$, Yoshiteru SATO ${ }^{1}$, Michio KURIYAGAWA ${ }^{1}$, Norio TENMA ${ }^{1}$, Hideo KOBAYASHI ${ }^{1}$ and Isao MATSUNAGA ${ }^{2}$

1. National Research Institute for Pollution and Resources, AIST, MITI, Onogawa, Tsukuba 305

2. New Energy and Industrial Technology Development Organization

The DSCA (Differential Strain Curve Analysis) which was proposed by Strickland and Ren in 1980 was applied to measure in-situ stress in the Kan-etsu 2nd tunnel. The basic assumption of the DSCA is that microcracks will be generated in a rock specimen by the stress relief when it is taken from borehole and the microcrack density is related to the earth stress. The object of this study is to validate this method. The overburden of the boreholes from which test specimens were taken was about $800 \mathrm{~m}$. Fourteen test pieces were carefully formed into a cubic shape with a side length of about $30 \mathrm{~mm}$. Total number of 18 foil strain gages were attached to each test piece, and hydro-static pressure up to about $50 \mathrm{MPa}$ was applied on the test piece. The directions of principal strains were calculated using the outputs of 18 strain gages as a function of hydro-static pressure. From the relations between hydro-static pressure and principal strain, the directions of in-situ principal stresses were estimated. As a result, azimuths of principal stresses estimated from fourteen samples had almost the same tendency, although the dips of those were divided into two groups of different tendency. The ratio of the maximum, intermediate and minimum principal stress was estimated using both Strickland and Ren's method and Dey and Brown's method. The ratio estimated by the former method was 1.00:0.69:0.42 while the latter gave the ratio of 1.00:0.64:0.45. Finally, these results estimated from DSCA were compared with another method such as hydraulic fracturing method or stress relief methods. There were no apparent contradiction between these results.

KEY WORDS: DSCA, DSA, In-situ Stress, Hydraulic Fracturing

\section{1. はじめに}

岩盤内にエネルギーや王気を貯蔵するための大規模な地下空間 を構築しようとする場合, その安定性を評価するために原位置に おける初期地圧の大きさや方向を知ることが重要となる。また， 地下深部から高温岩体のエネルギーを取り出すための人工的なき 裂を水王破砕によって造成しようとする場合にも，初期地王の大 きさや方向を知ることは重要である。岩盤内の初期地王を測定す る方法として, 現在までにいくつかの方法が提案されている。こ れらは, 原位置試験法と実験室における試験法とに大別すること ができる。すなわち, 前者は原位置において孔井等を用いて直接 初期地王を測定する方法で, 後者は孔井より採取されたコアを用 いて実験室で測定を行う方法である。このうち, 原位置試験法と しては,
1) 水王破砕法 ${ }^{1)}$
2) 応力解放法 ${ }^{2)}$

* 1991 年 1 月 25 日受付 4 月 2 日受理

1. 正会員 工博 公害資源研究所資源開発部

2. 正会員 公害資源研究所資源開発部

3. 正会員 工博 公害資源研究所 首席研究官

4. 正会員 新エネルギー・産業技術総合開発機構地熱技術開発室

キーワード：D S C A, D S A, 原位置応力, 初期地圧, 水圧破碎
3）ボアホール・ブレークアウト法 ${ }^{3)}$

4） AEの発震メカニズムによる方法 ${ }^{4)}$

等が代表的な方法として挙げられる。一方, 実験室における実験 法としては,

5) $\mathrm{D} \mathrm{S} \mathrm{C} \mathrm{A}^{5)}$

6) カイザー効果を用いた A E 法 ${ }^{6)}$

7) 変形率変化法 ${ }^{7)}$

8) 非弾性ひずみ回復法 ${ }^{8)}$

等を挙げることができる。一般に初期地圧の測定箇所が深くなれ ばなる程, 原位置試験のための設備は大きくなり, 実験に要する 費用も大きくなる。これに対して実験室実験の長所は, 方位の明 らかなコアを得ることができれば，実験精度を比較的容易に向上 させることができ，実験数も数多く行うことができる点にあり， ルーチン化することによって時間と費用とが節隇されることが期 待できる。本報では上述の実験室実験のうち，D S C Aに着目し， 関越トンネル二期線工事の現場から得られたコアを用いて初期地 王の推定を行った結果について述べる。

\section{D S C A の概略}

Strickland ${ }^{5)}$ により提案されたD S C A (Differential Strain Curve Analysis) は定方位コアを用いた初期地圧の推 
定法であり，一回の実験から三次元的な初期地圧の方向と, 最大, 中間抢よび最小主応力の大きさの比とを同時に求めることが可能 であるという長所を有している。D S C A では, コアに静水圧を 加え周圧と主ひずみとの関係から初期地压の状態を推定している。 この方法が適用可能であるための前提条件として,

1) 試料コア内部には, 応力解放時すなわち地下からのコアが 地表へ取り出される際に微小き裂が発生し,

2)この微小き裂の発生する方向は, 初期地圧に垂直な面内で あることが必要である。

ここで, 西松 ${ }^{9)}$ により提案されたレオロジー・モデルの一種で あるストッパーを用いて，ある主応力方向の応力とひずみとを関 連付けるモデルを考光ると図1のようになる。このモデルのうち， スプリング $\left(\right.$ コプライアンス $\left.\beta_{0}\right)$ とストッパ $\left(\right.$ すき間 $\left.\eta_{0}\right)$ と が並列に配置された要素は, 応力解放により発生するき裂に関連 する要素であり，また単独のスプリング( コンプライアンス $\left.\beta_{\mathrm{m}}\right)$ は，マトリクス部を表す。このモデルに応力を加えるとひずみー 応力線図は図 2 のようになる。この図 2 では横軸に応力, 綎軸に ひずみをとっており，ひずみ一応力線の傾きはコンプライアンス を表すこととなる。図 2 を参考として, 応力が解放された状態か ら，このレオロジー・モデルに対して徐々に応力を増加させてい くと，見かけコンプライアンスが $\left(\beta_{0}+\beta_{m}\right)$ の傾きでひずみが 増加する。その後, 応力が増加し, ストッパーが作動した時点で, $\beta_{0}$ のコンプライアンスを持つスプリングの全体びずみの増加に 対する寄与がなくなり，ひずみ一応力線の傾きは $\beta_{\mathrm{m}}$ となる。ま た, びずみ一応力線で, 傾き $\beta_{\mathrm{m}}$ を持つ直線部を外挿するとひずみ 軸との交点がストッパのすき間 $\eta_{0}$ を与えることとなる。

既に述べたようにD S C A では，コアに周圧を加え，周圧と主 ひずみとの関係から主応力の大きさの比を求めている。これを求 める方法としてS trickland $~^{5)}$ とDay $~^{10)}$ により，それぞれ別 の方法が提案されている。西松のモデルを使って両者の方法を整 理すると以下のようになる。

3) Strickland らが提案した方法では, 最大，中間および最 小の各主ひずみ方向の $\beta_{0}$ の比を主応力の大きさの比と関連付け,

4) Day らが用いた方法では, 各主ひずみ方向の $\eta_{0}$ の大きさ の比を主応力の大きさの比と関連付けている。

松木 ${ }^{11)}$ により指摘されているように， $\beta_{0}$ は考えている方向の き裂密度に関係する量である。また， $\eta_{0}$ はき裂の全閉塞量に関俰 する量であるので，当然のことながら両者の方法では異なった物

\section{$\beta_{0}$ Released}
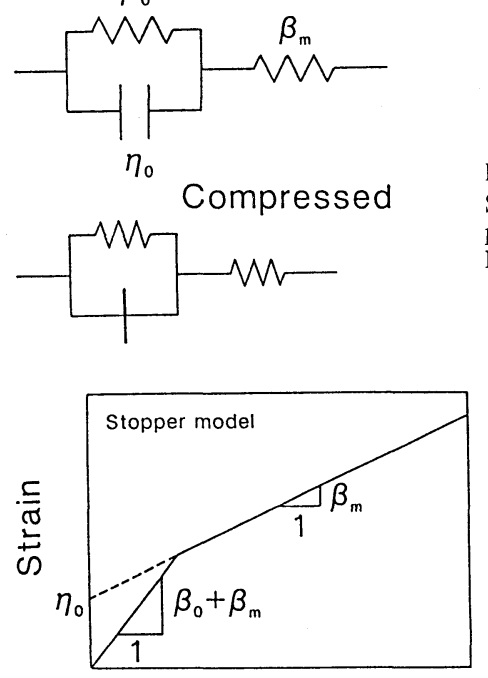

Stress
Fig. 1

Stopper model proposed by Nishimatsu9).
理量を解析の対象としていることになる。本報では, 簡単のため, Strickland らの方法をコンプライアンス法, Day らの方法をギ ヤップ法と呼ぶことにし，コンプライアンス法とギャップ法の両 者を用いて解析を行い, 解析結果にどの程度の差異が生じるかを 検討することにする。

\section{D S A の検討}

Strickland $~^{5)}$ の行ったD S C Aの実験では, 周圧ベッセル の中で岩石試験片と同時に, ひずみみ゙ージを貼り付けた溶融石英 ガラスを加圧し両者のひずみの差をとることによって，温度や計 測器等のドリフトを相殺している。この方法は Si mmons ら ${ }^{12)}$ に より提案されたDSA (Differential Strain Analysis)と呼ば れる方法であり，この方法を用いると $2 \times 10^{-6}$ のひずみの測定精 度が得られるとされている。このD S A は実験的には巧妙な手法 であるが, 岩石試験片のひずみを直接測定しないため, 岩石試験 片のひずみの絶対值を求めるためには石英ガラスの圧縮率が必要 である。また, 温度や計測器等のドリフト等がうまく相殺できれ ば良いが，場合によっては実験誤差が集積される可能性がないと は言えない。

D S C Aの実験においては，ひずみを精度良く測定する必要が あることは言うまでもない。そこでD S A を用いることの得失を 実験的に検討することとした。そのために, 溶融石英ガラスのみ を周圧ベッセル内で加圧し, 周圧とひずみとの関係を求めた。周 知のように, 溶融石英ガラスは内部にほとんど微小き裂が存在せ ず，これを静水仕で加圧した場合，周圧とびずみとの関係は完全 な直線となることが期待される。この実験のために用いた石英ガ ラス（東芝セラミックス製 T-1030）は 1 辺が $50 \mathrm{~mm}$ の立方体形 状をしており，互いに $45^{\circ}$ の角度をなす 3 素子型の口ゼットゲー ジを立方体の各面に 1 枚ずつ貼り付け, 合計で18成分のひずみ成 分を測定することとした。石英ガラスからのリード線をデータロ ガーと結線する際にハンダ付けを行う必要がある。この際にひず みを観測すると，ハンダ付け直後からひずみは大きく変動する。 そこで，以下に述べる岩石試験片に対する実験も含め，ハンダ付 けが終了してから少なくとも半日以上放置し, 実験装置全体の温 度が安定してから，実験を行うこととした。石英ガラスにより得 られた18成分のびずみの内, 勾配が最も大きいものと小さいもの
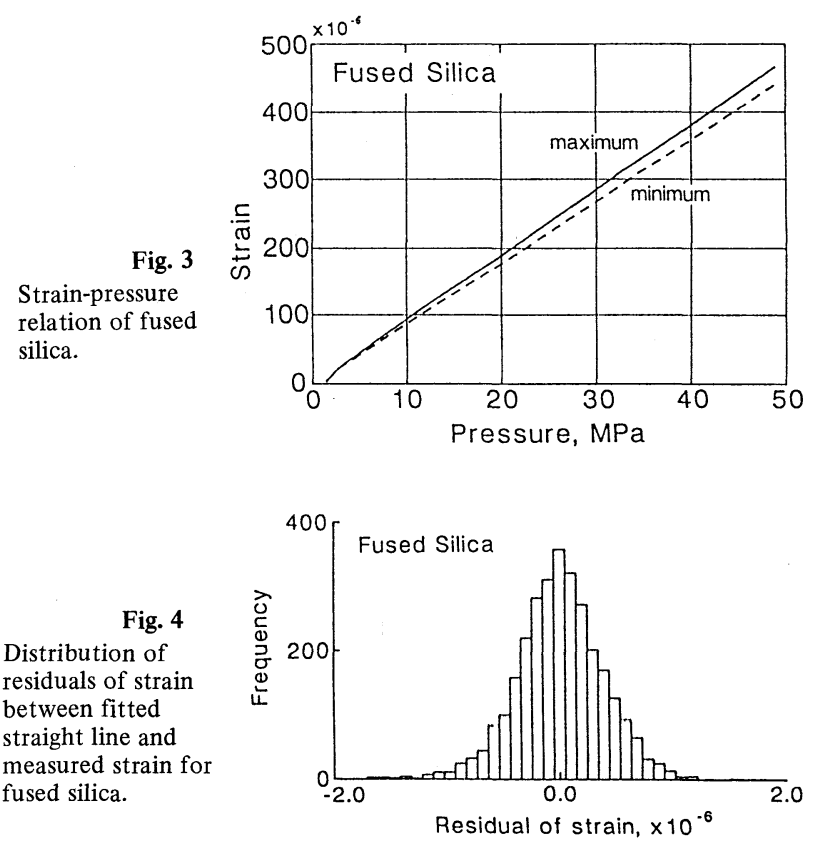

Fig. 2

Strain-stress relation of the stopper model. 
とを図 $3 に$ 示す。この図から分かるように周压とひずみとの間に は極めて良好な直線関係がある。そこで18枚のひずみみゲージのう ち, 明らかに挙動のおかしい 2 枚と周圧の小さい部分とを除いて, 各ひずみゲージより得られた測定値に対して最小自乗法を用いて 直線回帰を行い，回帰式と測定値との残差を計算して，その分布 を図4に示した。この図 4 から明らかなように残差の平均值はほ ぼゼロであり，系統的な片寄りも見られず,また標準偏差も 0.40 $\times 10^{-6}$ であるので, 前述のD S Aにより達成できるとされる $2 \times$ $10^{-6}$ の精度よりも良い。そこで, この実験結果から，D S Aを用 いなくても十分な精度が得られると判断し, 以下に述べるD S C Aの実験では岩石試験片のみを周圧べッセル内で加圧することと した。

\section{4. 試 料 岩 石}

試料岩石コアは関越トンネル二期線工事の現場から得られたも のである。この試料が採取されたボーリング孔では, 佐藤ら ${ }^{13)}$ より水王破砕法を用いた応力測定の実験も実施されている。この 水圧破砕法によって推定された実駼結果については，DＳＣAに よる実験結果と対比するために後述することとする。試料岩石コ アが採取された場所は, 湯沢側坑口から約 $4.5 \mathrm{~km}$ の距離にある集 塵室用のトンネルであり,この付近の被りはお拉よそ $800 \mathrm{~m}$ であ る。ボーリング孔の配置を図 5 に示すが，このトンネルの方位は ほぼ $\mathrm{N} 20^{\circ} \mathrm{W}$ であり（以下，本報では磁北を $\mathrm{N}$ とる），トンネ ル断面は高さ約 $8 \mathrm{~m}$, 幅約 $12 \mathrm{~m}$ の馬嵭形である。図 5 のようにト ンネルの床面に直径 $66 \mathrm{~mm}$, 長さ約 $15 \mathrm{~m}$ の孔井を 4 本掘削した。 このうち 1 本はほぼ鉛直 (V孔井)であり, 他の 3 本 ( I 1 I I 2 およ

Table 1 Mechanical properties of sample rock.

\begin{tabular}{lcccc}
\hline Item & & Number & Average & $\begin{array}{c}\text { Standard } \\
\text { deviation }\end{array}$ \\
\hline $\begin{array}{l}\text { Uniaxial compressive } \\
\text { strength }\end{array}$ & $(\mathrm{MPa})$ & 36 & 225 & 18 \\
$\begin{array}{l}\text { Brazilian tensile } \\
\text { strength }\end{array}$ & $(\mathrm{MPa})$ & 63 & 9.9 & 1.0 \\
$\begin{array}{l}\text { Young's modulus } \\
\text { Poisson's ratio }\end{array}$ & $(\mathrm{GPa})$ & & 57.4 & 2.3 \\
\hline
\end{tabular}

び13孔井）は鉛直方向より約 $30^{\circ}$ 傾いている。

コアリングに際しては, 孔井の切口部にN方向を記載し, コア 全長にわたってN方向を定めた。コアが天然き裂等により切断さ れている部分については, 目視によって切断部をはさむ上下のコ アの方位を合わせることとした。しかしながら，目視によって方 位を決定することが著しく困難な箇所もあり，これらのコアは厳 密な意味での定方位コアとは言えない。コア薄片の顕微鏡観察に よれば,この岩石は完晶質の花崗閃緑岩で, 平均の粒径は $0.5 \mathrm{~mm}$ 程度であり, また変質作用はほとんど受けていない。このコアの 代表的な力学的性質を表 1 に示す。

\section{5. 実験装置および実験方法}

実験方法は以下の手順によった。

まず，上述の現場において得られたコアのうち比較的堅固な部 分を選び, この部分から 1 辺の長さが約 $30 \mathrm{~mm}$ である立方体試験 片を合計で14個作成した。これらの試験片にはKTS 01からKTS 14 までの名前を付けたが, それぞれの試験片がどの孔井のどの深 度から得られたかを図6に示す。図 6 から分かるように，1.つの 孔井のほぼ同一の深度からは 2 個ずつの試験片を作成しており， $\mathrm{V}, \mathrm{I} 1$ およよ゙ $\mathrm{I} 3$ 孔井からは各 4 個ずつ, I2 孔井からは 2 個の試験 片を作成した。この立方体試験片にはN方向および孔井内での上 下方向が明らかになるように印を付けた。びずみゲージは有効長 $5 \mathrm{~mm}$ の単軸の䇴ゲージを用い, 立方体の各面について互いに $45^{\circ}$ の角度をなすように 3 枚ずつ, 合計で18枚のひずみゲージを用い た。図7に示す座標系を参考にすると, $\mathrm{x}, \mathrm{y}$ および $\mathrm{z}$ 方向には 4 枚ずつ, また $\mathrm{xy}, \mathrm{yz}$ および $\mathrm{zx}$ 方向には各 2 枚ずつのひずみゲー ジを貼り付けたことになる。ここでxy 方向とは $\mathrm{xy}$ 平面上で, $\mathrm{x}$ 軸および $\mathrm{y}$ 軸と互いに $45^{\circ}$ の角度をなす方向である。びずみゲー ジの接着には 2 液混合型のエポキシ系接着剤を用い, 硬化するま で最低で 24 時間的 $0.02 \mathrm{MPa}$ の王力を重錘によって加えた。なお， コア試料表面の目詰めを目的として, ゲージの接着を行う前に上 記の接着剤を試料表面に塗り込み, 接着剤が乾燥した後に, サン ド・ペーパで表面を滑らかにした。接着の完了したひずみゲー ジに電気信号線を付けた後, 周圧を加えるための油がコア試料の

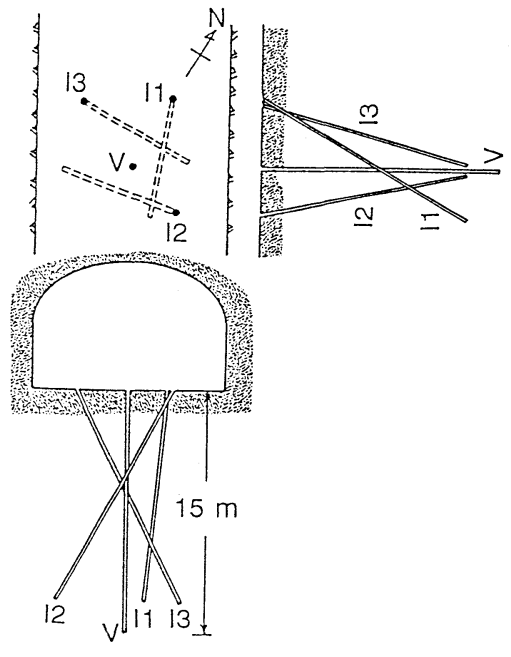

Fig. 5 Schematic view of boreholes in Kan-etsu tunnel from which DSCA samples were taken.

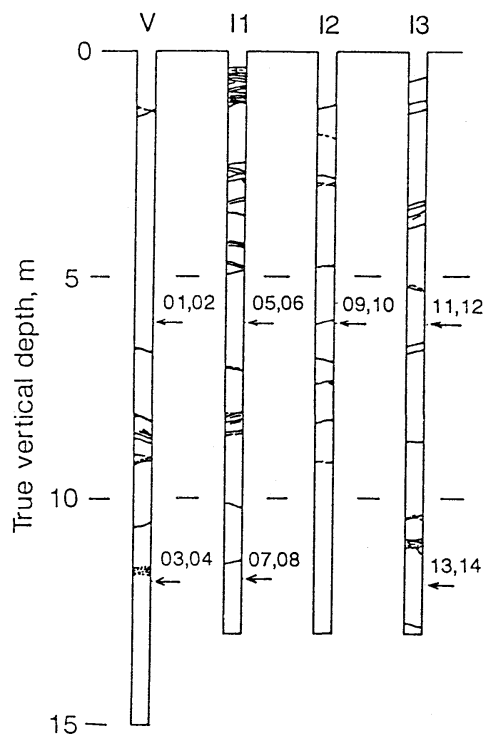

Fig. 6 Schematic view of boreholes with natural fractures. Numbers with arrow show the positions from which the DSCA samples were taken.

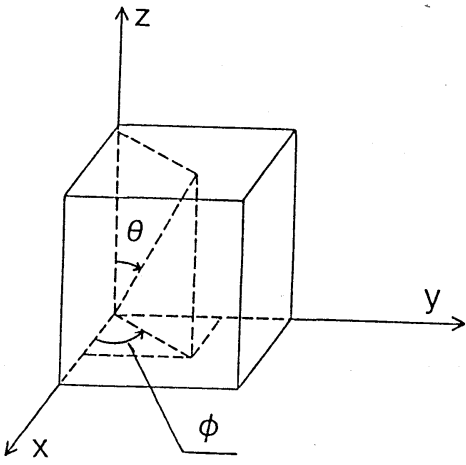

Fig. 7 Coordinate system of DSCA sample. 


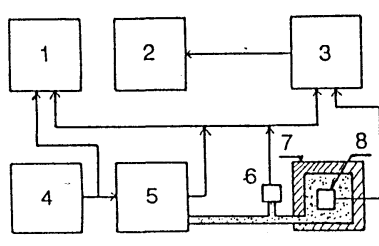

1) time-pressure recorder,

2) data acquisition computer,

3) data logger,

4) pressure controller,

5) servo-controlled pressure unit,

6) pressure transducer,

7) pressure vessel

8) DSCA sample.

Fig. 8 Block diagram of experimental apparatus.

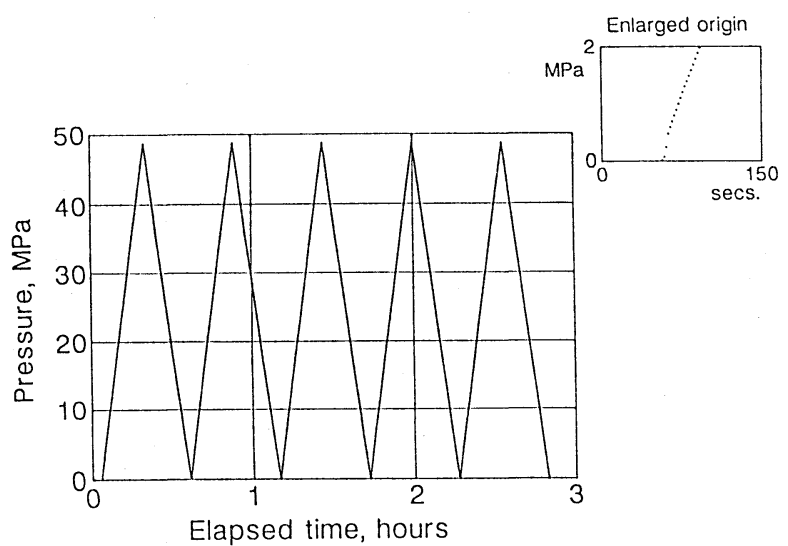

Fig. 9 Pressure history applied to fused silica and DSCA samples.

内部に浸透しないようにシリコンゴムでコア試料全体を 3 度にわ たって被覆した。

実験装置全体の模式図を図 8 に示す。試験片に静水圧を加える ための周圧ベッセルは, 常用耐圧が約 $50 \mathrm{MPa}$ である。この周圧 ベッセルには周囲に 6 個の電気信号取出し用の小孔が開いており, 各孔には 5 組 (10本) のリード線を持つ端子をはめ込むことがで きるので, 合計で30組のひずみ信号が取出せる構造となっている。 またベッセル内部に周圧を加えるためのブースタ・ポンプはサー ボ制御式となっており，外部から与えるリファレンス電圧に追 随して圧力が変化するようになっている。本実験では, 図9に示 すように, 周圧べッセル内の試料コアに增加あるいは減少を直線 的かつ周期的に繰り返す最大值約 $50 \mathrm{MPa}$ の三角波を 5 周期加え た。周化の増加あるいは減少速度は試験片 KTS 01 のみが約 0.10 $\mathrm{MPa} / \mathrm{s}$ であり,他の試験片では全て約 $0.05 \mathrm{MPa} / \mathrm{s}$ である。なお, Si mmons ら ${ }^{12)}$ によるD S Aの実験では, 周圧をステップ状に増 加させ, 各ステップにおいて周圧を一定の值に保持し，ひずみが 安定するまで 1 時間程度待ってから計測を行っている。この方法 を用いると 1 回の実験時間が長くなるため, 上述のような一定の 速度で周压を増加させることとした。周圧を複数回の周期にわた って加えた理由は, 今後, D S C A との併用を検討している変形 率変化法が静水王下に拉いても適用が可能か否かについてのデー タとするためである。従って, D S C A の解析では第 1 周期の 周圧の増加する際に得られた周圧とびずみの関係のみを用いた。 なお, 本ブースタ・ポンプでは装置の性能上, 第 1 周期目の加氏 の開始時に最大で $2 \mathrm{MPa}$ 程度の周王が急激に加わるという久点が ある。また，18成分のひずみおよび周圧の測定はデータ・ロガー を用いて行い, 全ての試験片について 2 秒に 1 回の割合でデータ を採取した。

\section{6. 実験結果および検討}

ここでは, 上述の14個の岩石試験片を用いて得られた実験結果

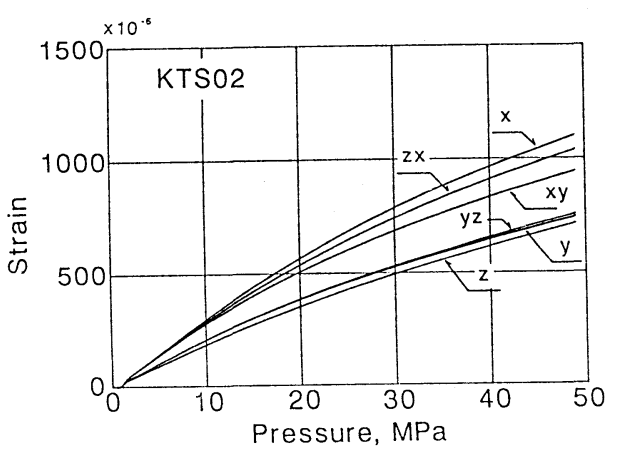

Fig. 10 Relations between pressure and strain for KTS02.

のうち, まず試験片 KTS 02 およびKTS 0702 例を選んで詳細な 解析結果を示し, その他の試験片については一括して示すことと する。

\section{6・1 試験片KTS 0 2 より得られた実験結果}

図10 では岩石試験片 KTS 02 を加圧した際に得られた周圧と $\mathrm{x}, \mathrm{y}, \mathrm{z}, \mathrm{xy}, \mathrm{yz}$ および $\mathrm{zx}$ 方向のひずみとの関倸を示す。ひず みの符号は圧縮を正としている。既に述べたようにこれらの方向 にはそれぞれ複数枚のひずみゲージが貼り付けてあり，図中では， 各方向の平均值, 例えば $\mathrm{x}$ 方向では 4 枚のひずみゲージの平均值 を示す。この岩石試験片 KTS 02 は図 6 で示したように鉛直な孔 井V孔から得られた試験片であり，図7で示した座標系を用いる とxの正の方向が $\mathrm{E}$ 方向, $\mathrm{y}$ の正の方向が $\mathrm{N}$ 方向, $\mathrm{z}$ の正の方向が 孔井の鉛直上向きの方向と一致する。この図10から明らかなよう に,いずれの方向のひずみも上に凸な滑らかな曲線となっている。 上述のように, 岩石試験片には合計で 6 方向に対してひずみゲ 一ジが接着されており, 最大, 中間および最小主ひずみの大きさ とそれぞれの主ひずみの方向を解析的に計算することができる。 これら主ひずみの大きさおよび方向は周圧を増加させるとともに

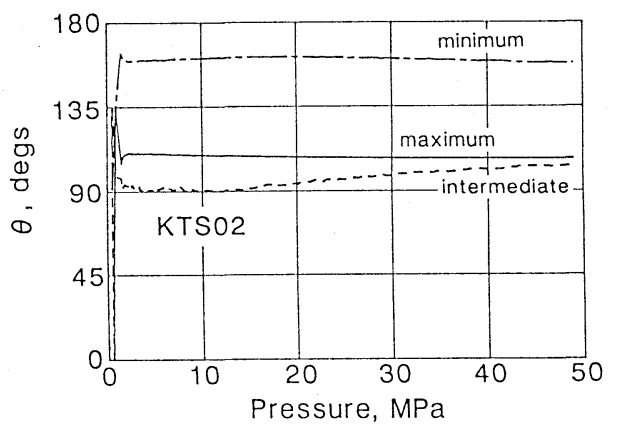

Fig. 11 Relations between pressure and direction of principal strain for KTS02. $\theta$ is the angle between the direction and z-axis as shown in Fig. 7.

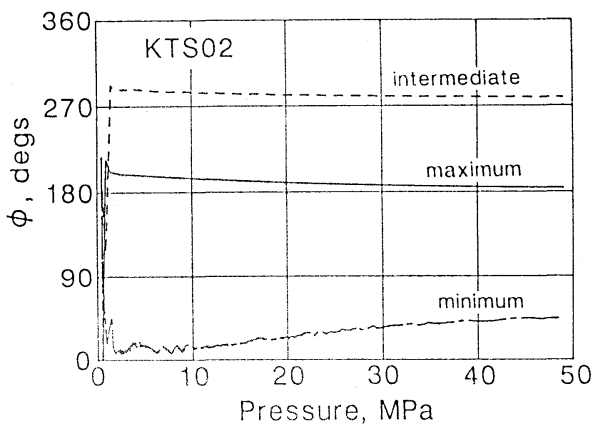

Fig. 12 Relations between pressure and direction of principal strain for KTS02. $\phi$ is the angle between the direction and $\mathrm{x}$-axis as shown in Fig. 7. 


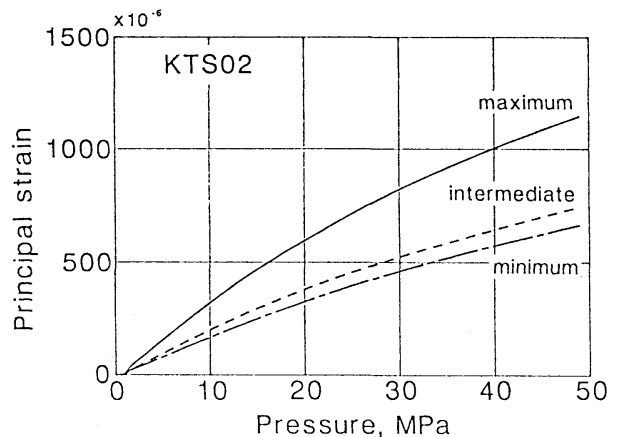

Fig. 13 Relations between pressure and analysed principal strain for KTS02.

変化する。図11および図12では，主ひずみの方向が周圧を増加 させるとどのように変化するかを示している。図11で示した $\theta$ は 図 7 を参照して，ある主ひずみの向が $\mathrm{z}$ 軸となす角度であり， $0^{\circ} \leqq \theta \leqq 180^{\circ}$ の範囲を持つ。また，図 12 で示した $\phi$ は，同じく 図 7 を参照して，ある主ひずみの方向を $\mathrm{xy}$ 平面に投影した方向 が $\mathrm{x}$ 軸となす角度であり, $0^{\circ} \leqq \phi \leqq 360^{\circ}$ の範囲を持つ。この図 11 および図12から明らかなように主びずみの方向は, 加圧開始から $2 \mathrm{MPa}$ 以降である一定の方向に徐々に収束することが分かる。例 えば, 最大主ひずみの方向は $\theta$ が $108^{\circ} に, \phi か ゙ 183^{\circ}$ にそれぞれ収 束している。D S C Aではこの方向を初期地圧の主応力の方向と することになる。

次に図13に, 最大, 中間および最小のそれぞれの主びずみの大 きさを計算して，横軸を周圧としてプロットした。この図から分 かるように中間ひずみと最小ひずみの大きさはほぼ同じであり， 最大びずみは他のひずみの 4 ～ 5 割程度大きな值を持っている。 この主ひずみー周圧曲線から初期主応力の比を求めるために，ま ずュンプライアンス法を適用することにする。図13に示した主ひ ずみ一周圧曲線から各主ひずみ曲線に対してほぼ原点付近のコン プライアンス(図 2 では $\beta_{0}+\beta_{\mathrm{m}}$ に相当する) から，周圧が大き くなって主ひずみ一周圧線図がほぼ直線となった部分でのコンプ ライアンス (図 2 では $\beta_{\mathrm{m}}$ に相当する)の差をとれば, ストッパー と並列なスプリングのコンプライアンス $\left(\beta_{0}\right)$ を求めることがで きる。コンプライアンス法では, 各主ひずみの方向の $\beta_{0}$ の比が初 期主応力の比となる。これらのコンプライアンスを図12より求め た後, 得られた $\beta_{0}$ より計算される主応力の比 (最大主応力の大き さを基準值とした）をまとめて表 2 に示した。

一方, ギャップ法を適用するために, まず, 図13に扔いて周圧 が十分に大きくなった時点での各主びずみ曲線の直線部分を外挿 してひずみ軸との交点の大きさを求めれば，これが各主ひずみ方

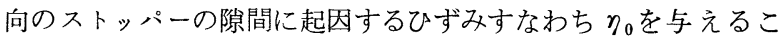
とになる。ギャップ法では各主ひずみの方向の $\eta_{0}$ の比が初期主応 力の比を与えることになるので, これらの值をまとめ, 初期主応 力の比を計算すると表了のようになる。

表 2 および表 3 で示したように, 推定された最大, 中間および 最小主応力の比はコンプライアンス法で $1.00: 0.60: 0.43$ となり, ギャップ法では 1.00: 0.53:0.43となる。従って, 兩者の方法から はほぼ同一の主応力比が得られたことになる。

\section{6・2 試験片KTS07より得られた実験結果}

次に，KTS 07 より得られた主ひずみ一周圧曲線を図14に示す。 図14では参考のために周圧が十分に大きくなった時点での外挿直 線をそれぞれの主ひずみ一周圧曲線に当てはめた結果についても 示してある。この主びずみ一周圧曲線に対して初期主応力の比を 求めるために，まずコンプライアンス法を適用することにする。
Table 2 Estimated ratio of magnitudes of principal stresses for KTS02 using "Compliance method".

\begin{tabular}{lcccc}
\hline $\begin{array}{l}\text { Direction of } \\
\text { principal strain }\end{array}$ & $\begin{array}{c}\beta_{1}+\beta_{\mathrm{m}} \\
\left(\mathrm{GPa}^{-1}\right)\end{array}$ & $\begin{array}{c}\beta_{\mathrm{m}} \\
\left(\mathrm{GPa}^{-1}\right)\end{array}$ & $\begin{array}{c}\beta_{1} \\
\left(\mathrm{GPa}^{-1}\right)\end{array}$ & $\begin{array}{l}\text { Stress } \\
\text { ratio }\end{array}$ \\
\hline Maximum & 0.03158 & 0.01714 & 0.01444 & 1.00 \\
Intermediate & 0.02027 & 0.01164 & 0.00863 & 0.60 \\
Minimum & 0.01712 & 0.01086 & 0.00626 & 0.43 \\
\hline
\end{tabular}

Table 3 Estimated ratio of magnitudes of principal stresses for KTS02 using "Gap method".

\begin{tabular}{lcc}
\hline $\begin{array}{l}\text { Direction of } \\
\text { principal strain }\end{array}$ & $\eta_{0}\left(\times 10^{-6}\right)$ & Stress ratio \\
\hline Maximum & 362.5 & 1.00 \\
Intermediate & 192.7 & 0.53 \\
Minimum & 156.3 & 0.43 \\
\hline
\end{tabular}

Table 4 Estimated ratio of magnitudes of principal stresses for KTS07 using "Compliance method".

\begin{tabular}{llccc}
\hline $\begin{array}{l}\text { Direction of } \\
\text { principal strain }\end{array}$ & $\begin{array}{c}\beta_{1}+\beta_{\mathrm{m}} \\
\left(\mathrm{GPa}^{-1}\right)\end{array}$ & $\begin{array}{c}\beta_{\mathrm{m}} \\
\left(\mathrm{GPa}^{-1}\right)\end{array}$ & $\begin{array}{c}\beta_{1} \\
\left(\mathrm{GPa}^{-1}\right)\end{array}$ & $\begin{array}{c}\text { Stress } \\
\text { ratio }\end{array}$ \\
\hline Maximum & 0.03479 & 0.01675 & 0.01804 & 1.00 \\
Intermediate & 0.02389 & 0.01320 & 0.01069 & 0.59 \\
Minimum & 0.02102 & 0.01024 & 0.01078 & 0.60 \\
\hline
\end{tabular}

Table 5 Estimated ratio of magnitudes of principal stresses for KTS07 using "Gap method".

\begin{tabular}{lcc}
\hline $\begin{array}{l}\text { Direction of } \\
\text { principal strain }\end{array}$ & $\eta_{0}\left(\times 10^{-6}\right)$ & Stress ratio \\
\hline Maximum & 450.0 & 1.00 \\
Intermediate & 224.0 & 0.50 \\
Minimum & 282.3 & 0.63 \\
\hline
\end{tabular}

各主ひずみの曲線に対してコンプライアンスを求めると, 表 4 で 示した值が得られ，同じくこの表中で示した主応力比が得られる。 この表 4 で示したように中間主びずみの方向の $\beta_{0}$ の大きさは $0.01069 \mathrm{GPa}^{-1}$ であり, 最小主ひずみの方向の $\beta_{0}$ の值は $0.01078 \mathrm{GPa}^{-1}$ であるので, 両者に大きな差異はないものの, 前 者が後者よりも小さいという実験結果が得られた。

一方，ギャップ法を適用すると表5に示した結果が得られた。 この方法を適用した場合にも，前述のコンプライアンス法と同様

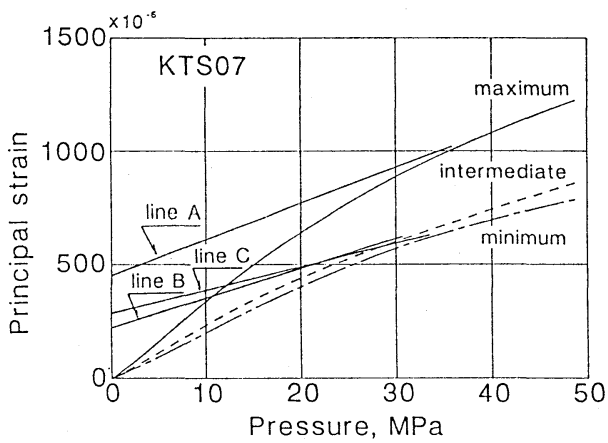

Fig. 14 Relations between pressure and analysed principal strain for KTS07. Straight lines A, B and C are the extrapolated lines on the high pressure part of each principal strain. 
に, 最小主ひずみの方向ではなく中間主ひずみの方向の $\eta_{0}$ の大き さが最も小さい。すなわち, 図14から分かるように図中Cで示した 最小主ひずみの外挿線のひずみ軸の切片は図中 B で示した最大ひ ずみの切片よりも大きな值を持っている。

従って, コンプラ゙イアンス法あるいはギャップ法のいずれの方 法を適用してもKTS 07 の試験片からは中間主ひずみの方向の主 応力が最も小さい值として推定されるという, 一見矛盾した結果 が得られたことになる。このような実験結果が報告された例は今 までにないが，これは次のように考えるべきであろう。すなわち， 例えばコンプライアンス法を例にとれば, 主応力比を決定するの はそれぞれの主ひずみの方向の $\beta_{0}$ の大きさの比からであり, 主ひ ずみそのものの大きさからではない。すなわち, 岩石コアに対し て静水王を加えた際に観測される最小主ひずみの方向が, 必ずし も最小初期地圧の方向と一致する保証があるわけではない。従。 て, この試験片のように中間主びずみの方向で最小の $\beta_{0}$ が得られ た場合には, この方向はもともと最小初期地圧の方向であったと 考えるべきであろう。ギャップ法についても同様である。そこで， この試験片 KTS 07 では中間初期地圧および最小初期地圧の加わ っていた方向は，それぞれ最小主ひずみの方向および中間主ひず みの方向であると推定することとした。

なお，このKTS 07 の試験片のように，中間主ひずみおよび最 小主ひずみの方向と推定された中間初期地圧および最小初期地压 の方向とが一致しなかった試験片はこの試験片のみであり, 他の 13 個の試験片ではいずれもこれらの方向は一致した。

\section{$6 \cdot 3$ その他の試験片より得られた実験結果}

前節までで試験片 KT S 02 およびKT S 07 の具体的な解析例に ついて述べた。ここでは同様の解析方法を他の試験片について適 用した結果についてまとめて述べることにする。まず，主ひずみ の方向から推定された初期主応力の方向を孔井別にウルフ・ネッ トの下半球に投影した結果を図15の(a)から(d)までに示す。なお, 図15の(b)から(d)までの, 傾斜井から得られた岩石試験片について はN方向に関する補正を行っていることは言うまでもない。これ らの各図を見ると, 同一の孔井から得られた試料片による各主応 力の方向の推定結果はいずれの孔井においても, 方位・傾斜とも

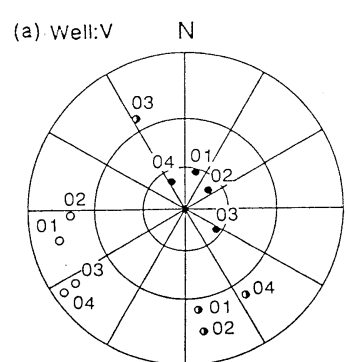

(c) Well:12

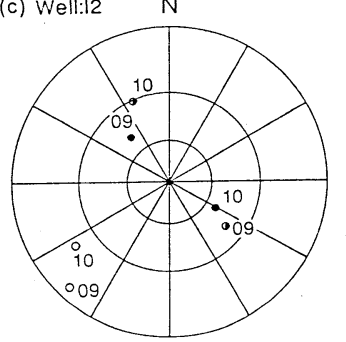

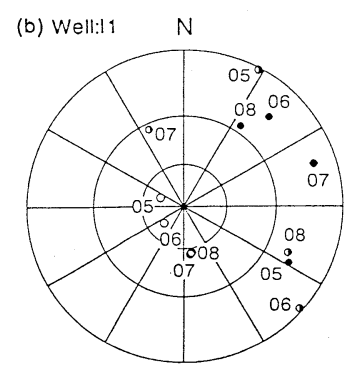

(d) Well:13 $\quad \mathrm{N}$

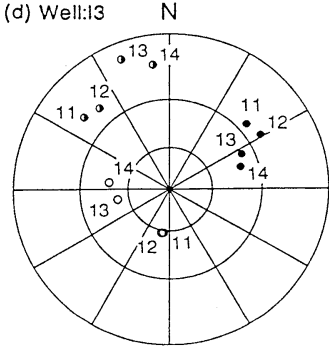

Fig. 15 Estimated directions of principal stresses of samples taken from: (a) well V; (b) well I1; (c) well I2; (d) well I3 on lower hemisphere of Wolf net. Open, half-solid and solid circles show the directions of maximum, intermediate and minimum principal stresses, respectively.
Table 6 Estimated ratio of magnitudes of principal stresses by "Compliance method" and "Gap method".

\begin{tabular}{ccc}
\hline Sample name & Compliance method & Gap method \\
\hline KTS01 & $1.00: 0.80: 0.44$ & $1.00: 0.68: 0.34$ \\
KTS02 & $1.00: 0.60: 0.43$ & $1.00: 0.53: 0.43$ \\
KTS03 & $1.00: 0.79: 0.47$ & $1.00: 0.71: 0.48$ \\
KTS04 & $1.00: 0.80: 0.52$ & $1.00: 0.73: 0.54$ \\
KTS05 & $1.00: 0.53: 0.37$ & $1.00: 0.50: 0.44$ \\
KTS06 & $1.00: 0.54: 0.14$ & $1.00: 0.54: 0.32$ \\
KTS07 & $1.00: 0.59: 0.60$ & $1.00: 0.50: 0.63$ \\
KTS08 & $1.00: 0.75: 0.54$ & $1.00: 0.60: 0.48$ \\
KTS09 & $1.00: 0.55: 0.55$ & $1.00: 0.67: 0.58$ \\
KTS10 & $1.00: 0.78: 0.50$ & $1.00: 0.73: 0.57$ \\
KTS11 & $1.00: 0.58: 0.33$ & $1.00: 0.57: 0.37$ \\
KTS12 & $1.00: 0.51: 0.43$ & $1.00: 0.46: 0.42$ \\
KTS13 & $1.00: 0.95: 0.22$ & $1.00: 0.95: 0.26$ \\
KTS14 & $1.00: 0.81: 0.34$ & $1.00: 0.80: 0.38$ \\
\hline
\end{tabular}

Magnitudes of intermediate and minimum stresses are normalized by the magnitude of maximum stress.

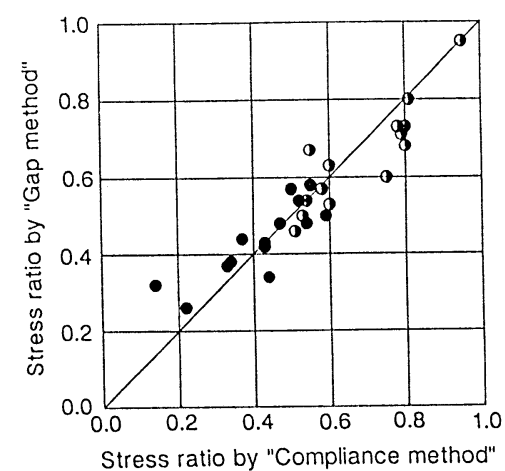

Fig. 16 Relation between estimated principal stress ratios by "Compliance method" and "Gap method ". Half-solid circles and solid circles show ratios of intermediate and minimum principal stresses to maximum principal stress, respectively.

にほぼ一致していることが分かる。これに対して, 異なった孔井 から得られた結果を比較すると，2つのグループに分けることが できる。1つのグループはV 孔井とI2孔井からなるグループであ り, もう 1 つのグループは, I1孔井とI3孔井からなるグループで ある。グループ内では最大, 中間および最小の主応力の方位およ び傾斜はお扩よそ一致している。しかしながら，グループ間を比 較すると各主応力の方位は一致しているものの, 傾斜は異なって いることが分かる。

次にコンプライアンス法およびギャップ法によって推定した主 応力の大きさの比をまとめて表 6 に示す。この表 6 で示した数值 をもとにコンプライアンス法とギャップ法とから得られた結果の 間に明確な差異があるかどうかを検討することとした。図16では 横軸にコンプライアンス法, 縦軸にギャップ法によってそれぞれ 推定された主応力の比をとって, 各試験片コアより得られた中間 および最小主応力の比をプロットした。このような罒上で実験結 果を整理した場合，ある試験片でコンプライアンス法とギャップ 法によって全く同一の応力比が得られたならば, プロットされる 点は図 16 に示す傾き $45^{\circ}$ の直線上に乗るはずである。図 16 から分 かるように, 主応力の比を表す点はほぼ傾き $45^{\circ}$ の直線の付近に 位置し, この直線より特に上あるいは下に片寄る等の傾向は見ら れない。このことからある試験片コアに対してコンプライアンス 法とギャップ法のいずれの方法を用いてもほぼ同一の結果が得ら れることが分かる。 
Fig. 17

Estimated directions of principal stress on lower hemisphere of Wolf net. Open, half-solid and solid circles show the directions of maximum, intermediate and minimum principal stresses respectively. The directions named HF, SR1 and SR2 were estimated by hydraulic fracturing tests by Sato 13 ) stress relief method by Saito 14 and stress relief method by Hirata 15 ), respectively.

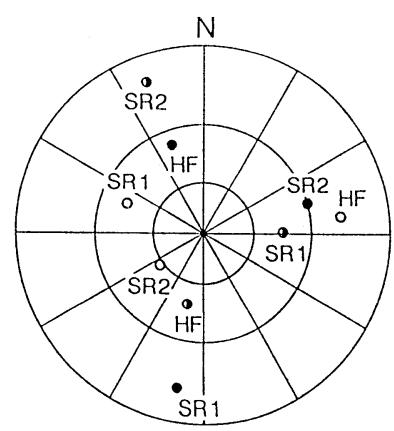

\section{7. 他の方法による実験結果との比較}

関越トンネルでは本報で述べたD S C A ばかりではなく, 他の 方法によっても初期地王の測定が実施されている。佐藤ら ${ }^{13)}$ は, 本岩石試験片の得られた孔井内での水圧破砕実験より主応力の大 きさと方向とを求めた。計測された主応力の方向は, 最大主応力 が $\mathrm{N} 83^{\circ} \mathrm{E}$, 中間主応力が $\mathrm{N} 167^{\circ} \mathrm{W}$ であり, 最小主応力の方向は $\mathrm{N} 20^{\circ} \mathrm{W}$ である。ま, 推定された主応力の大きさは, $18.3 \mathrm{MPa}$ ， 2. $7 \mathrm{MPa}$ および $1.7 \mathrm{MPa}$ という值であった。

次に, 斉藤ら ${ }^{14)}$ は, 関越トンネル二期線内ではなく, 一期線の トンネル内の 3 筒所において 8 素子坑底ゲージを用い, 応力解放 法によって初期地圧の測定を行った。この 3 箇所の内, 本D S C $\mathrm{A}$ 試験片が採取された箇所とほぼ同一の地質条件, 深度 (閃緑岩, $960 \mathrm{~m})$ で行われた実験結果からは, 主応力の值として, 22.9 $\mathrm{MPa}, 10.7 \mathrm{MPa}$ おび $7.5 \mathrm{MPa}$ という值が得られており, また それぞれの方向は真北に対して $76^{\circ} \mathrm{W}, \mathrm{N} 82^{\circ} \mathrm{E}, \mathrm{N} 177^{\circ} \mathrm{W}$ であ った。

一方, 平田 ${ }^{15)}$ は, 関越トンネル二期線内で本D S C A の試験 片の得られた箇所とほぼ同一の箇所（被り $820 \mathrm{~m}$ ) において, 応 力解放法の一種である球状坑底ひずみ法を用いて, 主応力状態を 計測しており, 主応力方向は最大, 中間および最小の順に真北に 対して $47^{\circ} \mathrm{W}, \mathrm{N} 152^{\circ} \mathrm{E}, \mathrm{N} 113^{\circ} \mathrm{W}$ あ゙った。また, 主応力比は $1.00: 0.47: 0.33$ となっている。

これらの結果をもとに, 主応力の方向を図17にまとめた。この 図17とD S C Aにより得られた主応力の方向の図すなわち図15を 比較すると以下のことが分かる。すなわち，方位に関してはD S $\mathrm{C} A$ およびその他の手法で得られる測定結果はおおよそ一致して いる。これに対して傾斜を比較すると，D S C A で得られた(b)と (d)のグループと 2 つの応力解放法で得られた值とはおおよそ一致 しており，同じくD S C A で得られた(a)と(c)のグループと水圧破 砕法で得られた結果とが, 大体一致している。従って, D S C A

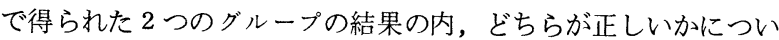
ては不明であるものの, いずれのグループの結果を選んでも，D S C A 以外の手法で得られた結果と一致する。

Table 7 Comparison between estimated principal stress ratio by different methods.

\begin{tabular}{lc}
\hline Method & Ratio of principal stresses \\
\hline DSCA ("Compliance method") & $1.00: 0.69: 0.42$ \\
DSCA ("Gap method") & $1.00: 0.64: 0.45$ \\
Hydraulic fracturing13) & $1.00: 0.15: 0.09$ \\
Stress relief 14) & $1.00: 0.47: 0.33$ \\
Stress relief 15$)$ & $1.00: 0.25: 0.21$ \\
\hline
\end{tabular}

次に, 中間および最小主応力の最大主応力に対する比を一括し て表 7 にまとめた。この表から明らかなように，D S C Aによる 比はコンプライアンス法あるいはギャップ法のいずれを適用して も，その他の手法よりも大きめの値が得られた。

\section{8. おわりに}

本報では，関越自動車道の関越トンネル二期線の工事現場より 得られた14個のコアに対してD S C A を適用し, 初期地圧の推定 を行った。その結果，以下の知見が得られた。

1）D S C Aにより推定した初期主応力の方位はいずれの試験 片でもおおよそ一致した。

2）これに対して, 推定した初期主応力の傾斜は孔井毎での複 数個の結果を比較するとおおよそ一致するものの, 孔井間を比較 すると異なった傾斜を持つ 2 つのグループのあることが分かった。

3） D S C A では, 主応力比を推定する方法としてS tri ckland らおよびDeyらにより，それぞれ別の方法が提案されている。本 報では両者の方法を適用して主応力比を求めたが，いずれの方法 でもほぼ同一の值が得られた。

4）DＳＣＡにより得られた結果を，同一の現場において実施 された水圧破砕法および応力解放法による測定值と比較すると, 主応力の方向に関しては両者は調和的であった。これに対して, 主応力の比に関してはD S C Aによる結果は, その他の結果と比 較して大きめの值が得られた。

原位置における真の応力状態を知ることは困難であるが，D S C A を用いた場合に測定結果のばらつきが比較的少ないこと，ま た得られた結果が他の方法による実験結果と調和的であることか ら, D S C A を用いて地下の応力状態を実験から推定することは ある程度可能であると考える。しかしながら，D S C A の概略の 項で述べた応力解放時のき裂の発生機構については十分な解明が なされているとは言えない。今後はこの点について理論的な検討 を進めるとともに実験例を増やすことが重要である。

謝辞試験片コアの作製方法等については, 山口大学工学 部佐野修助教授および工技院地質調査所の西澤修主任研究官に貴 重なご助言を頂いた。また, 試料の採取に関しては関越トンネル 二期線の工事事務所関係者のお世話になった。ここに記して感謝 の意を表する。

\section{参 考 文 献}

1）例えば水田義明他：日本鉱業会誌，103[1188]，75～85, (1987)

2）例えば鈴木光他：日本鉱業会誌, 83 [950]，793〜 799，(1967)

3) Zoback, M. D. et al.: J. Geophys. Res., 90, 5523 5530, (1985)

4）佐々木俊二他：地震学会講演予稿集, B 44, 秋季大会, (1990)

5) Strickland, F.G. and N.K. Ren : Proc. 21 st. U. S. Rock Mechanics Symposium, Rolla, Missouri, (1980)

6）金川 忠他 : 電力中央研究所報告, 研究報告 $381004,(1981)$

7) 山本清彦他 : 地震学会講演予稿集 No.1, 春期大会, $(1983)$

8) Warpinski, N.R. and L.W. Teufel : SPE 15368, 61 st. Annual Technical Conference and Exhibition of the SPE, New Orleans, LA, (1986)

9) 西松裕一: 材料, 20, 129 135, (1971)

10) Dey, T.N. and D.W. Brown : International Symposium on Rock Stress and Rock Stress Measurements, Sweden, (1986)

11）松木浩二：地殼応力計測 ワークショップ資料集，92〜104, (1989)

12) Simmons, G. et al.: J. Geophys. Res., 79, 4283 4385, (1974)

13）佐藤嘉晃他：第 22 回岩盤力学に関するシンポジウム講演要旨集, $441 \sim 445,(1990)$

14) Saito, T. et al. : 5 th. International Conference ISRM, Melbourne, Australia, (1983)

15) Hirata, A. et al.: submitted to International Conference ISRM, Aachen, German, (1991) 